\title{
The importance of sustainable phosphorus management in the circular economy (CE) model: the Polish case study
}

\author{
Marzena Smol ${ }^{1}$
}

Received: 7 June 2018 / Accepted: 18 September 2018 / Published online: 29 September 2018

(c) The Author(s) 2018

\begin{abstract}
In the transition to the circular economy (CE) model, the sustainable management of raw materials plays a key role in the whole value chain. One of the most important critical raw materials (CRM) for the European economy is Phosphorus (P), which cannot be replaced by any other element. This paper presents the current $\mathrm{P}$ management structure in Poland taking into account the sources of $\mathrm{P}$, its consumption and recycling. At present, no phosphates are produced in Poland and the demand for P-bearing raw materials is satisfied entirely by imports. There is high potential for recovery of P from selected secondary sources due to an increase in the generation of P-rich waste, such as municipal and industrial sludges (947.2 thous. $\mathrm{Mg}$ of dry solid waste in 2016), sewage sludge ash (45 thous.Mg /year) or biomass ash (4.2 million Mg/year); however, $\mathrm{P}$ recycling is not commonly undertaken in Poland. In order to transfer the Polish economy to the CE model, the government is working on strategies and programmes that take into account the sustainable management of raw materials. The most promising sources of $\mathrm{P}$ are municipal and industrial wastewater, sewage sludge and sewage sludge ash and, therefore, basic legal recommendations for nutrient recovery in the wastewater sector were proposed by Polish organisations dealing with environmental concerns. The paper also presents the basic action thatis recommended to be undertaken with the objective of improving the sustainable management of this CRM in the Polish economy.
\end{abstract}

Keywords Phosphorus $\cdot$ Recovery/recycling technologies $\cdot$ Zero waste $\cdot$ Circular economy $(\mathrm{CE}) \cdot$ Sustainable management

\section{Introduction}

Sustainable development (SD) is a global strategy adopted by countries all over the world which indicates the necessity to integrate the economic, environmental and social aspects of all activities in order to meet the needs of present and future generations [1]. Currently, the implementation of SD principles in the European Union (EU) is realised by transition to the model of a circular economy (CE), where the added value of products is retained as long as possible and waste is eliminated $[2,3]$. In the CE model, special attention is paid to critical raw materials (CRMs) which are economically and strategically important for the European economy, but have a high-risk associated with their supply [4].

Marzena Smol

smol@meeri.pl; smol@min-pan.krakow.pl

1 Mineral and Energy Economy Research Institute, Polish Academy of Sciences, Wybickiego 7A str., 31-261 Cracow, Poland
One of the most important CRMs for the European economy which cannot be replaced by any other element [5] is phosphorus $(\mathrm{P})$, which is an element essential for human nutrition, with limited resource [6]. As Europe has no significant $\mathrm{P}$ mines [7], it is highly dependent on the import of $P$ ore [8]. Phosphate rock is unevenly distributed across the globe, which results in only a small number of countries controlling the world's remaining reserves [9]. The current worldwide $\mathrm{P}$ reserves are estimated at $67 \times 10^{9} \mathrm{Mg} \mathrm{P}$ and the world mining production in 2013 was $0.22 \times 10^{9} \mathrm{Mg} \mathrm{P}$. About $75 \%$ of known reserves are located in Morocco (the main exporter). United States of America, (USA) also has significant reserves but their P-based products are not sold on the global market, which further limits the source of supply as far as European countries are concerned. Strategically, Europe should be independent in the supply of P raw materials, and therefore, there is a significant need to look for P-rich residues, which can be important secondary sources of this CRM [10-12].

Action aimed at promoting proper management of $\mathrm{P}$ resources has already been taken in developed European 
countries such as Germany and Switzerland with the aim of achieving $\mathrm{P}$ security in the domestic economy. From the beginning of 2016, P recovery and recycling from sewage sludge and slaughterhouse waste has been obligatory in Switzerland. The new regulation was introduced with a transition period of 10 years. Switzerland claims to be the first country in the world to oblige resource recovery. The new regulation was introduced with a transition period of 10 years. Switzerland claims to be the first country in the world to oblige resource recovery [86]. One of the newest German regulations, which should help in making them independent of external sources of $\mathrm{P}$ supply, is the new sewage sludge ordinance which entered into force on 1st January 2018 [87]. This step makes $P$ recovery from sewage sludge obligatory on all German wastewater treatment plants (WWTPs) larger than 50,000 person equivalents (p.e.), that is around $66 \%$ in WWTPs larger than 50,000 p.e. in Germany. They have to recover the phosphorus if the sludge contains more than $2 \%$ $\mathrm{P} / \mathrm{DS}$ (dry solids) or have to incinerate the sludge in monoincinerators. Moreover, in Germany, a special dedicated network of stakeholders from science, industry and public bodies: Deutsche Phosphor Platform (DPP) was created in order to establish a sustainable model of phosphorus management through more efficient use of $\mathrm{P}$ as well as effective recycling and reprocessing. Currently, Switzerland and Germany have taken a lead in environmental engineering solutions and have identified several ways of recovering $\mathrm{P}$ from different waste streams. These countries promote an interdisciplinary systems thinking approach in the development of proposals for regulations and recommendations for policy makers. Following the legislative developments in Switzerland and Germany, Austria is also opting for mandatory P recovery from sewage sludge to maintain their security of this raw material and close the P cycle. Unfortunately, in most European countries, $P$ use currently involves waste and losses at every stage in its lifecycle.

An important European region where the sustainable management of nutrients is especially important is the Baltic region. The effects of nutrient enrichment (mainly by phosphorus, nitrogen and other elements), also known as eutrophication, are perhaps the single greatest threat to the Baltic Sea environment. Phosphorus presence in the Baltic is a consequence of waterborne loads passing into the sea, mainly as wastewater with a high phosphorus content. Currently, the largest inputs of phosphorus (37\%) into the Baltic Sea originate from Poland (HELCOM, 2013). Therefore, it seems that for this country, the development of sustainable solutions aimed at more rational $\mathrm{P}$ management and keeping $\mathrm{P}$ in the economy should be a priority. The work focuses on the presentation of phosphorus as a CRM for the European economy, the importance of phosphorus recycling in the $\mathrm{CE}$ model and the $\mathrm{P}$ management structure in Poland taking into account the sources of $\mathrm{P}$, its consumption and its recycling.
Moreover, $\mathrm{CE}$ strategies and legal restrictions on the use of $\mathrm{P}$ are presented, next to the basic action that it is recommended should be undertaken (taking into account the economic, technical, social and environmental aspects of policy) with the objective of improving the sustainable management of this CRM in the Polish economy.

\section{Phosphorus as a critical raw material in Europe}

The new list of CRMs for the European economy was published on 13th September 2017. The European Commission (EC) underlined that the 2017 criticality assessment was carried out for 78 raw materials and based on this evaluation, 27 CRMs were chosen due to the risks of their shortage of supply in the EU and for which the impacts of a shortage on the economy are greater than those of most other raw materials. On the 2017 list, nine new CRMs were presented for the EU as compared to the 2014 list. In the list from 2014 [14], phosphate rock, an important source of phosphates, was indicated and it is included on the updated list in 2017 [4]. One of the CRMs on the extended list is phosphorus. It is assumed that the inclusion of phosphorus in the EU CRMs list will cause the development of EU policies promoting the sustainable management of $\mathrm{P}$ materials in the near future.

Europe has very limited primary resources of phosphorus materials [15] and is dependent on outside providers ( $88 \%$ for phosphate rock and $100 \%$ for phosphorus) [4]. The structure of phosphate rock and phosphorus import into Europe, based on the 2010-2014 average, is presented in Fig. 1. Phosphate rock is mainly imported from Morocco and Russia. Other significant actors in the structure of phosphate rock import are also Algeria and Syria. Almost 80\% of phosphorus is imported into Europe from Kazakhstan. The other main sources of imports of $\mathrm{P}$ are China and Vietnam. European production of phosphate rock is only carried out in Finland, but it has less than 1\% of the world's phosphate resources which is $287.5 \times 10^{9} \mathrm{Mg}$. The securing of $\mathrm{P}$ supply is made difficult by the fact that some of the main P suppliers are considered politically risky, which can cause major problems for the European economy [16].

\section{Phosphorus recycling in the circular economy (CE) model}

In their Communication [4] the EC provides for the "End-oflife recycling input rate" which measures the ratio of recycling from old scrap to EU demand of a given raw material (sum of primary and secondary material supply inputs to the EU). The estimated values of the end-of-life recycling input rate for phosphate rock is equal to $17 \%$, and for phosphorus 
Fig. 1 Structure of main exporters of phosphate rock and phosphorus to the EU (average 2010-2014). Source: own analysis based on (COM 490, 2017)

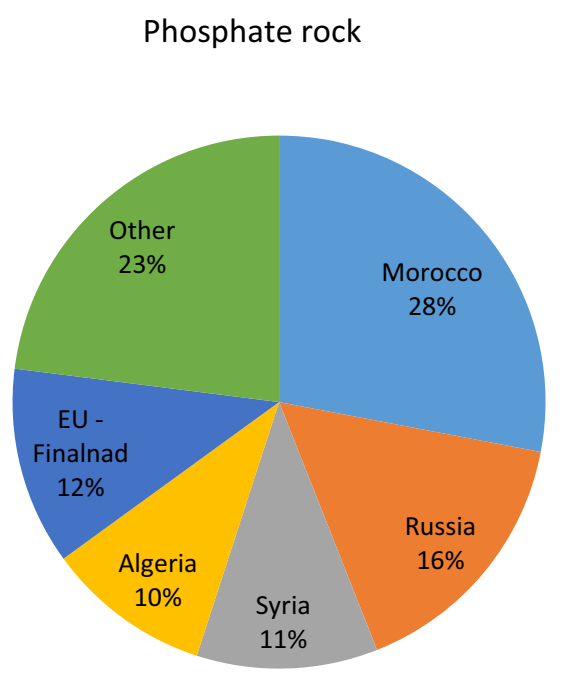

is $0 \%$. Due to the fact that the recovery of these P-materials is technologically possible, the "End-of-life recycling input rates" presented in Europe should be higher. Research and development $(\mathrm{R} \& \mathrm{D})$ and recovery and recycling policies are needed in this area. The concept of keeping $P$ materials and $\mathrm{P}$ products in use for as long as possible, thus maximising their utility and minimising their waste, is compatible with the Circular Economy (CE) model [3] promoted by the EU. By keeping the residues of $\mathrm{P}$ which originate in the $\mathrm{P}$ life cycle in such a way that $\mathrm{P}$ can be re-used in the economy can reduce losses of functional $P$ from the economy [17]; based on EC assumptions, higher and sustained improvements in $P$ resource efficiency performance can bring large economic benefits [3]. According to the EC Communication moving towards a more $\mathrm{CE}$ in all possible branches of industry is an essential way to deliver the resource efficiency agenda established under the Europe 2020 Strategy for smart, sustainable and inclusive growth [18]. The importance of the recycling of phosphorus was emphasised in the first EC Communication related to the CE in Europe "Towards a circular economy: A zero waste programme for Europe" [2]. Due to P losses at every stage of its lifecycle, the Commission started to develop a framework for further action (policy framework) aimed at a more sustainable use of $\mathrm{P}$, which includes selected issues such as recycling, fostering innovation, the improvement of market conditions and mainstreaming its sustainable use in EU legislation on fertilisers, food, water and waste [2]. A further step was the inclusion of $\mathrm{P}$ issues in the proposal for an action plan for the EU, published at the end of 2015. In the plan to close the loop, the Commission committed itself to taking a series of actions to encourage the recovery of $\mathrm{P}$ as one of the CRMs and prepare a report describing best practice and options for further action. Moreover, the EC was also encouraging action by Member States on this topic in its revised proposals on waste [3]. It also mentioned that recycled nutrients such as $\mathrm{P}$ are a distinct and significant category of secondary raw materials [5]. The quality and environmental standards related to the use of waste materials in fertiliser production differ for now across the Member States. In order to address this situation, the EC is working on a revision of the EU regulation on fertiliser use. This includes new ways of measurement to facilitate the EU-wide recognition of organic and waste-based fertilisers, thus stimulating the sustainable development of an EU-wide market $[2,3]$.

The next step taken by the EC relating to the use of waste as a component in fertilisers was the publication in 2016 of a CE Package laying down rules on the making available of CE marked fertiliser products on the market. Due to one of the main fertiliser constituents being phosphate rock, and taking account of Europe's need to import more than $90 \%$ of it, domestic P-rich waste could potentially cover about $20-30 \%$ of the EU's demand for phosphate fertilisers. The EU has indicated that there is a currently largely unexploited investment potential remaining in relation to this. An increase in recycling rates and reduction in import dependency for $\mathrm{P}$ are considered essential to European agriculture and are mentioned as one of the key objectives for the coming years, next to the revision of the EU Fertiliser Regulation in order to extend its scope to nutrients from secondary sources (e.g. recycled phosphates) and organic sources [19].

The inclusion of $\mathrm{P}$ issues in EU documents suggests that highly effective methods of $\mathrm{P}$ processing and recovery should be developed and implemented in European countries in the years to come [20-22]. According to the principles of a CE, the recovery of $\mathrm{P}$ from waste streams [23] arising from sources such as wastewater, sludge, sewage sludge ash, meat and bone meal, pig slurry and biomass is indicated [24]. By increasing the recovery of phosphates and phosphorus in various branches of industry, it is possible to achieve both economic (reduction of imports) and environmental (reuse of waste) benefits [25]. It needs to be mentioned that 
Table 1 Quality parameters of documented phosphate deposits. Source: Mineral Resources of Poland, 2017

\begin{tabular}{|c|c|c|c|c|}
\hline Deposit & $\begin{array}{l}\text { Diameter of phosphate } \\
\text { concretions (in mm) }\end{array}$ & $\begin{array}{l}\mathrm{P}_{2} \mathrm{O}_{5} \text { content in phosphate con- } \\
\text { cretes in the deposit profile }(\%)\end{array}$ & $\begin{array}{l}\text { Abundance of phosphate } \\
\text { concretions }\left(\mathrm{kg} / \mathrm{m}^{2}\right)\end{array}$ & $\begin{array}{l}\text { Abundance relative to the } \\
\text { criteria for the requirements } \\
\text { (in } \% \text { ) }\end{array}$ \\
\hline Annopol & $>10$ & 13.5 & 568 & 32 \\
\hline Burzenin & $>2$ & 18.1 & 385 & 21 \\
\hline Chałupki & $>10$ & 14.9 & 354 & 21 \\
\hline Gościeradów & $>2$ & 15.2 & 496 & 28 \\
\hline Iłża-Krzyżanowice & $>2$ & 18.6 & 791 & 44 \\
\hline Iłża-Chwałowice & $>2$ & 22.3 & 891 & 50 \\
\hline Iłża-Łęczany & $>2$ & 18.6 & 654 & 36 \\
\hline Iłża-Walentynów & $>2$ & 19.9 & 470 & 26 \\
\hline $\begin{array}{l}\text { Radom—Dąbrówka } \\
\text { Warszawska }\end{array}$ & $>2$ & 16.5 & $\begin{array}{l}\text { Upper series-317 } \\
\text { bottom series-460 }\end{array}$ & $\begin{array}{l}\text { Upper series-18 } \\
\text { bottom series_-26 }\end{array}$ \\
\hline Radom-Krogulcza & $>2$ & 19.1 & $\begin{array}{l}\text { Upper series-218 } \\
\text { bottom series-504 }\end{array}$ & $\begin{array}{l}\text { Upper series-12 } \\
\text { bottom series }-28\end{array}$ \\
\hline Radom-Wolanów & $>2$ & 15.4 & $\begin{array}{l}\text { Upper series-170 } \\
\text { bottom series }-447\end{array}$ & $\begin{array}{l}\text { Upper series-9 } \\
\text { bottom series-25 }\end{array}$ \\
\hline
\end{tabular}

methods of $\mathrm{P}$ recovery should be effective not only from a technological [26], environmental and economic [27] points of view, but also consistent with the social issues [28]. The above principles of $\mathrm{P}$ source management should be applied in both public and private companies [29], thus linking environmental and industrial management in order to achieve systematic $\mathrm{P}$ management in all aspects of their operation and offering efficient and effective recovery of phosphorus sources. It is one of the important ways for transition to the CE model of nutrient management in Europe.

\section{Management of phosphorus in Poland}

\section{Sources of phosphorus}

Phosphorus comes from primary (phosphate rock deposits) and secondary resources (waste streams). In the earth's crust, $\mathrm{P}$ exists in the form of phosphate rock, and this is mined. However global reserves of high-grade phosphate rock are dwindling. Phosphorus is also accumulated in secondary materials as both water and solid waste; therefore, they may be valuable sources of $\mathrm{P}$ for industrial and agricultural purposes [30].

Resources of mineral deposits are one of the most important elements of national wealth [31, 32]. Phosphate rocks occur in Poland in the area of Radom - Iłża - Annopol Gościeradów - Modliborzyce in various types of sediments in the form of concretions rich in calcium phosphates [33]. Deposits of phosphate concretions averaging $14 \% \quad \mathrm{P}_{2} \mathrm{O}_{5}$ have been identified in the NE part of the Świętokrzyskie Mountains. Exploitation of phosphate rock commenced in Poland in the interwar period. The ten deposits identified there provided resources that totalled 42.4 Mt of phosphates (7.35 $\mathrm{Mt}_{2} \mathrm{O}_{5}$ ), including $10.77 \mathrm{Mt}\left(1.47 \mathrm{Mt}_{2} \mathrm{O}_{5}\right)$ in the formerly-mined deposits at Annopol and Chałupki [34]. The mine in Chałupki closed in 1961, and that in Annopol in 1971. These resources were determined on the basis of the economic criteria used in the 1950s. In the early 1980s, new criteria were introduced and the economic value of these deposits became negligible due to the quality of the phosphate rock and the depth of the deposits. The current requirements for balancing criteria for phosphate rock sediments determine the maximum depth of the deposit documentation at $400 \mathrm{~m}$, the minimum $\mathrm{P}_{2} \mathrm{O}_{5}$ content in the phosphate rock constellations in the bed profile $-15 \%$ and minimum phosphate rock concessions at $1800 \mathrm{~kg} / \mathrm{m}^{2}$. The quality parameters of the documented phosphate deposits are presented in Table 1 [33].

The deposit richness parameter differs significantly from the requirements of balance criteria defining the minimum requirements for cost-effective operation. The geological resources of phosphate mineral reserves are hydrated, which would make any potential exploitation very difficult; moreover, significant fragments of them have either been built over or roads and railway lines, and high-voltage lines have been constructed across them. In extreme cases, this reduces the resources available for exploitation by as much as $50-80 \%$. Based on the above facts, those deposits have not been exploited and have been removed from the national resource balance [33].

Currently, no phosphates are produced in Poland and the demand for phosphorus-bearing raw materials is satisfied entirely by imports consisting primarily of phosphate concentrates. The structure of the import in Poland in 2016 is presented on Fig. 2. 


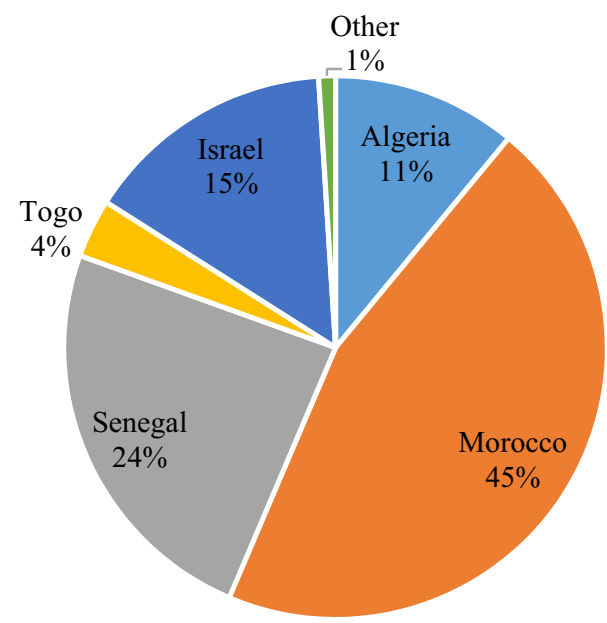

Fig. 2 Shares of the main exporters of phosphate rock and phosphorus to Poland in 2016. Source: (Environment, 2017)

\section{Consumption of phosphorus}

The phosphorus fertiliser market is one of the most important markets for agricultural production [36]. Approx. 90\% of $\mathrm{P}$ is used to produce food and animal feed [37]. In Poland, the main user of phosphate rock is the fertiliser industry (for the production of phosphate fertilisers); on a much smaller scale it is used by the chemical industry for the production of various other types of phosphorus compound. The Polish fertiliser industry produces about $1.1 \%$ of world phosphate fertilisers and it is one of the most significant sectors of the chemical industry. The structure of the use of inorganic $\mathrm{P}$ fertilisers in the Polish regions based on Eurostat is presented in Table 1. There is a visible decline in the use of phosphate fertilisers in all regions. Currently, the greatest demand for $\mathrm{P}$ fertilisers is observed in the eastern region of Poland, which has the largest agricultural area (Table 2).

Changes in the use of inorganic phosphorus fertilisers in
Table 2 Use of inorganic phosphorus fertilisers in the Polish regions in 2006-2015 $[\mathrm{Mg}]$ Source: ec.europa.eu/ Eurostat

\begin{tabular}{|c|c|c|c|c|c|c|c|c|c|c|}
\hline \multirow[t]{2}{*}{ Region } & \multicolumn{10}{|l|}{ Year } \\
\hline & 2006 & 2007 & 2008 & 2009 & 2010 & 2011 & 2012 & 2013 & 2014 & 2015 \\
\hline Central & 41,668 & 38,253 & 38,895 & 29,036 & 27,508 & 31,644 & 31,038 & 26,122 & 29,151 & 21,380 \\
\hline Southern & 11,666 & 10,581 & 10,927 & 9,118 & 7,787 & 11,059 & 8,421 & 5,053 & 8,215 & 7,152 \\
\hline Eastern & 42,973 & 38,135 & 43,069 & 34,186 & 32,657 & 36,911 & 34,629 & 35,716 & 36,301 & 31,274 \\
\hline North-western & 40,247 & 40,087 & 45,215 & 36,550 & 34,338 & 41,083 & 37,261 & 48,911 & 29,691 & 28,232 \\
\hline South-western & 18,747 & 18,857 & 26,274 & 22,522 & 20,243 & 23,632 & 20,267 & 26,510 & 19,792 & 17,783 \\
\hline Northern & 37,592 & 33,937 & 28,752 & 32,440 & 31,650 & 33,988 & 30,266 & 25,983 & 25,767 & 26,724 \\
\hline
\end{tabular}

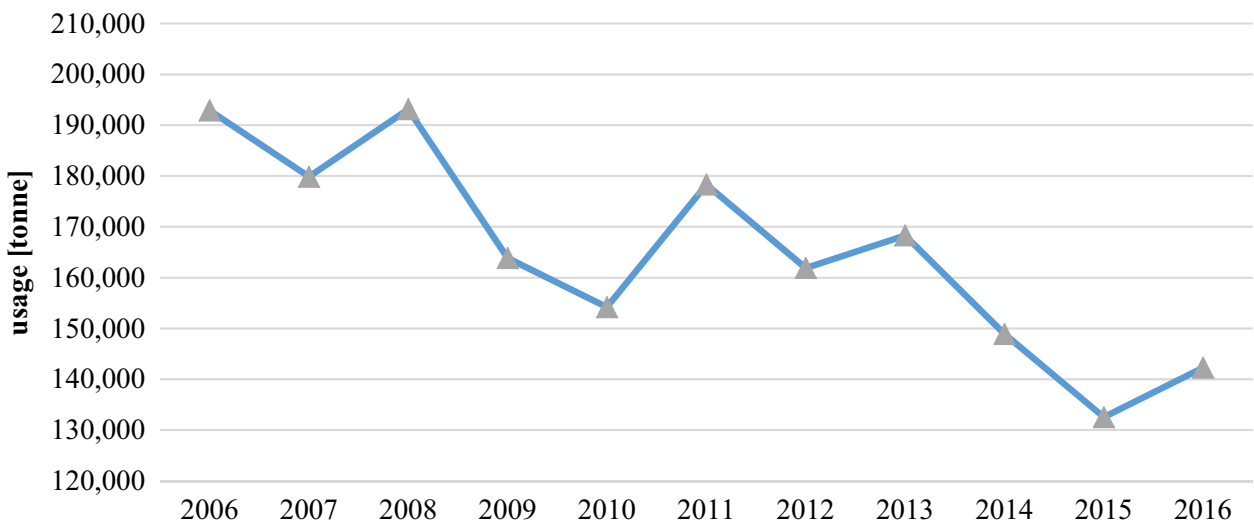

Fig. 3 Changes in the use of inorganic phosphorus fertilisers in Poland in 2006-2015.

Source: ec.europa.eu/Eurostat
Poland in 2006-2015 are illustrated on Fig. 3. The domestic market for P fertilisers is largely dependent on global and EU trends. In the years up to 2008, the amount of fertiliser used reached $193133 \mathrm{Mg} /$ year. Due to a drastic increase in fertiliser prices on a world scale (in 2007 by up to $42 \%$, in 2008 by up to $136 \%$ ), the consumption of $\mathrm{P}$ fertilisers decreased until 2010 [36]. In 2011, the consumption of phosphorous phosphorus in the domestic economy. 
fertilisers increased and since then it has steadily declined again. In 2016, it was 7\% higher than in 2015 and it reached $142281 \mathrm{Mg} / \mathrm{year}$. The demand is $100 \%$ covered by imports (Fig. 3).

\section{Recovery of phosphorus}

Due to the vital importance of $\mathrm{P}$ and its increasing scarcity as a natural resource, phosphorus recovery has recently gained significant scientific and technical interest [6]. In Poland, there is high potential for the recovery of $\mathrm{P}$ from secondary sources such as:

- municipal and industrial wastewater [38-41] ;

- sewage sludge (SS) [42-44];

- sewage sludge ash (SSA) [45-47];

- meat and bone meal [48-50];

- pig slurry [51,52];

- biomass $[53,54]$;

- industrial waste (as phosphogypsum waste from chemical production) [55].

The P-rich waste resource is large, for example the amount of SS generated in municipal and industrial WWTPs was 947.2 thousand $\mathrm{Mg}$ of dry solids in 2016 [35] approx. 45 thousand $\mathrm{Mg}$ of SSA per year [56] is produced in monoincineration plants and 4.2 million $\mathrm{Mg}$ of biomass ash [57] is produced from which a significant amount of $\mathrm{P}$ could be recovered. Despite the fact that the country could decrease its dependency on the global phosphate rock market through $\mathrm{P}$ recovery from waste $[30,58], \mathrm{P}$ recycling is not a commonly used practice in Poland. Many research groups have been working on the development of technological solutions for effective and efficient $P$ recovery from the various waste streams [59]. Their development has also included comparative studies focused on a technical and economic assessment [60] of the proposed technologies in order to identify those that are technically applicable and can be considered market-feasible alternatives to phosphate rock mining and conventional fertiliser production [61]. It should be also noted that the recovery of $\mathrm{P}$ from various waste streams as an environmentally-correct alternative is associated with economic concerns [62]. Since P recovery technologies require large investment costs and there are no legal requirements for nutrient recovery from waste streams, in the past companies did not invest in the implementation of P-recycling technologies in Poland. In order to turn the waste into fertiliser, the issue of heavy metals removal should be also taken into account [63].

As a result of changing trends in the waste sector, including the introduction of CE principles, new projects aimed at the recovery of nutrients are slowly starting to be introduced in the country. The Jarocin Waterworks Company has signed a contract for carrying out an investment under the project 'Modernisation and Extension of WWTP Jarocin'. The project includes the implementation of 5 tasks with a total value of 60 million EUR ${ }^{1}$, supported by co-financing from the European Union. The largest investment project is the construction of a station for the recovery of raw materials, such as nitrogen, phosphorus and biogas, at the sewage treatment plant in Cielcza. This would allow it to recover between 100 and $200 \mathrm{~kg}$ of fertiliser per year. The water and sewage management project carried out in the Jarocin commune won a prestigious award at the international Wex Global 2018 conference, which took place in Lisbon in March 2018. In the years that follow further development is expected together with the introduction on the market of technologies for the recovery of phosphorus, in particular in the wastewater sector [64].

\section{Towards a circular economy in phosphorus management in Poland}

\section{Strategies for a circular economy}

European countries and regions, such as Germany [65], the Netherlands [66], Finland [67] and Norway [68] have already launched their plans for a CE. The Polish Ministry of Development started to work on the implementation of CE principles within the national economy in 2016. An Interdepartmental Circular Economy Group has been established to propose actions aimed at introducing a CE under the Polish roadmap 'Transformation towards a circular economy' [69]. The group was divided into four thematic sub-groups focused on waste, bio-economy, business models and soft actions (education and promotion), which consist of industrial and socioeconomic partners from all parts of the Quadruple Helix, i.e. government, academia and research units, industry, NGOs and citizens. The objective of the group is to identify opportunities, threats, strengths and weaknesses in the context of the transition towards a CE, develop a position with regard to the EU initiatives related to the transition towards a $\mathrm{CE}$ and develop the Polish roadmap for the implementation of a CE. As a result of the reconstruction of the Polish government, from 1st January of 2018, the tasks related to the CE were taken over by the newly established Ministry of Entrepreneurship and Technology, which currently is working on a national action plan for a CE. One of the most important issues in the roadmap is the management of raw materials and waste according to CE principles. In the case of phosphorus this requires sustainable use of primary sources of $\mathrm{P}$ and directing as much $\mathrm{P}$-rich waste to recycling

\footnotetext{
$\overline{11 \text { EUR } ~ 4.2 ~ P L N . ~}$
} 
as possible. The proposed Polish roadmap 'Transformation towards a circular economy' indicated the directions and basic recommendations for the building of a CE in Poland. However, there is no specific information directly related to nutrient recovery. Those will be proposed in further regulations relating to waste management.

The Ministry of Environment is also working on the development and implementation of CE principles in Poland. In 2016, the 'CE Pilot Priority Programme' was established with the participation of five municipalitiesKrasnobród, Łukowica, Sokoły, Tuczno and Wieluń. The project is supported by the National Fund for Environmental Protection and Water Management (Towards a Circular Economy, 2016) and focuses on the development of best practices in the waste, water, energy and education areas towards developing a $\mathrm{CE}$ at local level. A further stage is an exchange of views and knowledge transfer to other Polish regions. The models of municipal management promoting a CE will thus be transferred to other Polish communities. The Ministry of the Environment also shares educational materials on the CE with both lecturers and students. This will help raise citizen awareness on the $\mathrm{CE}$ and ultimately lead to the implementation of CE principles in everyday life and then in business practice.

It should also be noted that the management of raw materials (RMs) is one of the main tasks of the Ministry of Environment. Currently, one of the most important projects related to RMs in Poland is the State Raw Materials Policy, which is the result of the work of the Ministry of Environment with the support of the representatives of all other ministries, business entities, etc., in particular those that form part of the Interdepartmental Group for the State Raw Materials Policy, scientific institutions and citizens. The development of the State Raw Materials Policy is based on nine pillars:

- The demand of the domestic economy for mineral RMs;

- obtaining RMs from mineral deposits and the heat of the Earth;

- the acquisition of RMs from waste, their substitutes and reclamation and remediation;

- obtaining scarce mineral resources by import and international cooperation;

- the legal conditions of the State's Raw Materials Policy;

- dissemination of knowledge about geology, mining and mineral resources;

- the institutional framework for the development and implementation of the State's Raw Materials Policy;

- risk and investment planning;

- improving the tax system and taxes.

The implementation of the RMs policy is to serve the rational management of mineral and raw material resources from secondary sources, as well as to determine the directions of geological and mining research and investments in accordance with the current state of knowledge and the stage of the country's development. One of the most important results expected from implementation of the RMs policy is the gradual implementation of the CE model by minimising the amount of waste and maximising the recovery of RMs from secondary sources, including the recovery of nutrients in the wastewater sector [70].

\section{Legal regulations}

In Poland, the most promising sources of $\mathrm{P}$ are municipal wastewater, industrial wastewater (low P amount), sewage sludge and sewage sludge ash [71] since the major part of the phosphate from wastewater is transferred to the sludge (approx. 90\%) [47]. Therefore, special attention should be paid to the introduction of legal regulations in the area of recovery of raw materials from the above waste streams and the development of new technologies for the recycling of nutrients in the wastewater sector.

Poland's problems relating to sludge management issues stem primarily from EU restrictions [72-74] placed on the conventional disposal and recovery options formerly used. Based on the implementation of Directive 99/31/EC on the landfill of waste [75], since 1st January 2016 it has not been possible to landfill completely untreated sewage sludge with a heat of combustion $>6 \mathrm{MJ} / \mathrm{kg}[76,77]$. The current structure of SS disposal is: $3.3 \%$ is directed to land reclamation, $14.1 \%$ is used in agriculture, $3.5 \%$ is used for the cultivation of plants, $10.3 \%$ is landfilled, $6.5 \%$ is in temporary storage, $20.6 \%$ is incinerated and $41.7 \%$ is disposed in other ways [35]. In the previous National Waste Management Plan 2014 [78] there was expected to be an increase in the volume of thermally transformed SS [79].

In Poland, there are more and more possibilities for $\mathrm{P}$ recovery from SSA associated with an increase in the volume of SSA generated in recent years arising from the new SS mono-incinerator plants which have been built next to large municipal WWTPs. In 2010, only three installations were operating with a total capacity of 37.3 thousand $\mathrm{Mg}$ of dry matter/year, and now there are 11 plants with a total processing capacity of 160.3 thousand $\mathrm{Mg}$ of dry matter/ year. It was indicated that average phosphorus content in ashes is around $9.7 \%$, though $3000-4000 \mathrm{Mg}$ of $\mathrm{P}$ per year can be recycled and introduced back into the environment from approx. 43,000 Mg SSA produced per year in Polish incineration plants $[42,71]$. At this moment, the SSA generated is stored together with other waste, but it is necessary to underline that only selectively stored SSA can be made available for $\mathrm{P}$ recovery. Therefore, new specially dedicated landfill sites should be designated for this purpose. At present, SSA is only stored separately on the area of the 
treatment plant in Gdynia. According to the objectives of the most recent National Waste Management Plan 2022 [80], rational management of products from the thermal treatment of SS, in particular storing SSA in a manner permitting the recovery of phosphorus, is indicated as one of the priority directions in the wastewater sector. Since the Polish government has underlined the necessity of $P$ recovery from the SSA already generated, the practical development of recycling of this material should be expected. However, according to the waste management hierarchy, burning is the last solution before safe storage. Therefore, in the first place it is necessary to look for solutions in the field of $\mathrm{P}$ recovery from wastewater and sewage sludge. This is also connected with the recommendations published in the Country Report Poland 2017 [81] where the EC proposes preparing national and regional waste management plans that would move Poland towards prevention and recycling rather than creating incineration overcapacities. Therefore, it should be expected that further recommendations, financial support tools and legal regulations on nutrient recovery from wastewater and sewage sludge will be proposed at a national and international level.

The necessity for the practical implementation of more sustainable disposal practices in the wastewater sector was highlighted by the Polish government in the official documents published by the Environment Committee of the Polish Senate. The first opinion of the Environment Committee on 17th of March 2016 relating to the innovative use of wastewater as a source of energy and resources [82] underlined the need to start work on the creation of appropriate legal provisions and the necessity to develop a strategy for the disposal and management of sewage sludge in Poland. Moreover, a dynamic development of research on phosphorus recovery from wastewater and sewage sludge in Polish conditions was highlighted as the expected way forward in future years. In the second opinion of 14th March 2017 on the inclusion of sewage sludge in the circular economy, the importance of investments in new and innovative solutions in the wastewater sector was identified as the main driving force in the transition to a circular economy model in Poland. Moreover, it was considered that it is necessary to develop a national sewage sludge management programme and support innovative solutions under the 'Infrastructure and Environment' operational programme for 2014-2020, and to develop a strategic research programme on the use of sewage sludge [83].

In addition, in the Opinion from 6th December 2017 on the protection of the Baltic Sea against pollution from sewage sludge in the context of the HELCOM recommendations, the Environment Committee positively assessed the position of the Helsinki Commission on sewage sludge, which proposed recirculation of nutrients, especially phosphorus, from sewage sludge as a recommended route towards better use of their valuable properties and energy potential, and to manage sediments in a safe, effective and sustainable manner. It is particularly important for Poland, which does not have a clear settlement strategy, associated investment and research programmes, or legislation regulating the recovery of nutrients from sewage sludge. It was also indicated that the country has begun research on the recovery of phosphorus from sewage sludge, which makes it possible to close the phosphorus cycle in nature, in line with the principles of a circular economy. It should also be pointed out that the Environment Committee supports the Ministry of the Environment in activities related to the preparation of the settlement strategy, taking into account the recommendations of the Helsinki Commission, and will seek the development of legal regulations regarding the recovery of phosphorus from sewage sludge under Polish conditions [84].

\section{Recommended policy directions}

The sustainable phosphorus management models should be developed in all European regions where current $\mathrm{P}$ usage involves waste and losses of this CRM. One of the most important European regions with significant problems with phosphorus is the Baltic Region. The effects of nutrient enrichment (mainly by phosphorus, nitrogen and other pollutants), also known as eutrophication, are perhaps the single greatest threat to the Baltic Sea environment. The presence of phosphorus in the Baltic Sea is a consequence of the waterborne loads entering the sea, mainly as wastewater with a high phosphorus content. It should be also pointed out that as a consequence of extensive runoff from intensive agricultural activities and the large population in southern part of the drainage basin, the largest source of phosphorus by far is from Poland [13]. Moreover, since $45 \%$ of the population of the drainage basin lives in Poland, it appears extremely important to propose recommendations for the sustainable use of phosphorus in this country [85].

Based on the experience of other European countries (such as Germany and Switzerland) which have already proposed solutions towards the sustainable management of $\mathrm{P}$ according to the $\mathrm{CE}$ model, the following policy directions should be adopted under Polish conditions:

\section{Legal recommendations:}

- The implementation of the EU requirements regarding the sustainable use of $\mathrm{P}$-sources in the economy;

- the development of proposals for regulations and recommendations for policy makers;

- the development of legal obligations on the recovery of $P$ from various waste streams; 
2) Financial support:

- the development of financial tools supporting research and development in the area of management, consumption and recycling of CRM resources;

- the development of programmes supporting investment in nutrient recovery technologies;

- the development of tools supporting the commercialisation of the research and the implementation of the nutrient recovery technologies on the market.

.) Organisational recommendations:

- The transfer of knowledge on the design of solutions for the sustainable use of $\mathrm{P}$ on a regional and national level, based on existing best management practices of $P$ usage in developed countries;

- the creation of a network platform aimed at collaboration on the regional and national level in the area of $\mathrm{P}$ management;

- the development of a mapping service dedicated to organising detailed information on secondary P sources in Poland.

4. Technical and environmental recommendations:

- Conducting research and development focused on nutrient recovery;

- the identification of the P recovery potential of different waste streams (the performance of installations across the country and the availability of recycled $\mathrm{P}$ );

- the development of environmental engineering solutions dealing with $\mathrm{P}$ recovery from different waste streams;

- the technical and environmental assessment of engineering solutions dealing with $\mathrm{P}$ recovery from different waste streams.

5. Social aspects:

- Initiating dialogue and promoting awareness-raising among all stakeholders: policy makers, industry, academia, researchers and the community on the implications of the scarcity of $\mathrm{P}$ on a global and national scale and possible sustainable solutions;
- the promotion of an interdisciplinary systems thinking approach by various awareness-raising activities, and close collaboration with local stakeholders;

- the promotion of the best management practices of sustainable phosphorus usage among local frames;

- building a 'Phosphorus Responsible Society' by educating the public about the diversity of $\mathrm{P}$ sources and the potential for good $\mathrm{P}$ management, fostering circular thinking, and developing entrepreneurial ideas related to this resource.

The policy directions identified could contribute to the development of a new management strategy for the sustainable use of phosphorus in Poland taking into account policy, economic, technical, social and environmental factors.

\section{Conclusions}

In the transition to the CE model, where the added value of products is kept as long as possible and waste is eliminated, the sustainable management of raw materials plays a key role. In above CE model, especial attention is paid to CRMs which are economically and strategically important for the European economy, but have a high-risk associated with their supply.

One of the most important elements which cannot be replaced and is an essential element for human nutrition, yet limited in resource is phosphorus. An importance of issues related to sustainable $\mathrm{P}$ management results from UE legislation, which indicated $P$ as a CRM.

The sustainable management of P-resources is especially important for the Baltic region. A consequence of waterborne loads passing into the sea, mainly as wastewater with a high $\mathrm{P}$ content, is the eutrophication of the Baltic Sea environment. Due to the largest inputs of $\mathrm{P}(37 \%)$ into the Baltic Sea originate from Poland, the development of sustainable solutions aimed at more rational $\mathrm{P}$ management for this country is externally important.

Poland has no $\mathrm{P}$ mines and the demand for P-bearing raw materials is satisfied entirely by imports, mainly from Morocco and Senegal. However, there is high potential for the recovery of $\mathrm{P}$ from secondary sources such as municipal and industrial wastewater, SS, SSA, meat and bone meal, pig slurry, biomass, industrial waste, and others. Despite the fact that Poland could decrease its dependency on the global phosphate rock market through $P$ recovery from above waste streams, $\mathrm{P}$ recycling is not a commonly used practice.

The Polish government works on the implementation of the CE principles to raw materials management. Since the most promising sources of $\mathrm{P}$ are municipal and industrial wastewater, sewage sludge and sewage sludge ash, special attention is paid to the introduction of legal regulations in 
the area of recovery of raw materials from the above waste streams and the development of new technologies for the recycling of nutrients in the wastewater sector.

Based on the experience of developed countries (such as Germany and Switzerland) which have already proposed solutions towards the sustainable management of $\mathrm{P}$ according to the CE model, the policy directions, which include the legal, technical and environmental recommendations next to the economic and social concerns, should be adopted under Polish conditions.

Acknowledgements This work was funded by the statutory research of the MEERI PAS and the InPhos project no. 17022 (2018-2019), which is financed by the EIT Raw Materials-a body of the European Union.

Open Access This article is distributed under the terms of the Creative Commons Attribution 4.0 International License (http://creativeco mmons.org/licenses/by/4.0/), which permits unrestricted use, distribution, and reproduction in any medium, provided you give appropriate credit to the original author(s) and the source, provide a link to the Creative Commons license, and indicate if changes were made.

\section{References}

1. Schreck M, Wagner J (2017) Incentivizing secondary raw material markets for sustainable waste management. Waste Manag 67:354-359

2. Commission of European Communities (2014) Communication. Towards a circular economy: a zero waste programme for Europe (COM no. 398, 2014)

3. Commission of European Communities (2015) Communication. Closing the loop-an EU action plan for the Circular Economy (COM no. 614, 2015)

4. Commission of European Communities (2017). Communication on the 2017 list of Critical Raw Materials for the EU (COM no. 490, 2017)

5. Senthilkumar K, Mollier A, Delmas M, Pellerin S, Nesme $\mathrm{T}$ (2014) Phosphorus recovery and recycling from waste: an appraisal based on a French case study. Resour Conserv Recycl 87:97-108

6. Ribarova I, Dimitrova S, Lambeva R, Wintgens T, Stemann J, Remmen K (2017) Phosphorus recovery potential in Sofia WWTP in view of the national sludge management strategy. Resour Conserv Recycl 116:152-159

7. Kalmykova Y, Fedje KK (2013) Phosphorus recovery from municipal solid waste incineration fly ash. Waste Manag 33(6):1403-1410

8. Gorazda K, Tarko B, Wzorek Z, Kominko H, Nowak AK, Kulczycka J, Henclik A, Smol M (2017) Fertilisers production from ashes after sewage sludge combustion-a strategy towards sustainable development. Environ Res 154:171-180

9. Pham HG, Harada H, Fujii S, Nguyen PHL, Huynh TH (2017) Transition of human and livestock waste management in rural Hanoi: a material flow analysis of nitrogen and phosphorus during 1980-2010. J Mater Cycles Waste Manage 19(2):827-839

10. Morita K, Guo M, Oka N, Sano N (2002) Resurrection of the iron and phosphorus resource in steel-making slag. J Mater Cycles Waste Manage 4(2):93-101
11. Pettersson A, Åmand LE, Steenari BM (2008) Leaching of ashes from co-combustion of sewage sludge and wood-part I: recovery of phosphorus. Biomass Bioenerg 32(3):224-235

12. Ohura S, Harada H, Biswas BK, Kondo M, Ishikawa S, Kawakita H, Keisuke O, Inoue K (2011) Phosphorus recovery from secondary effluent and side-stream liquid in a sewage treatment plant using zirconium-loaded saponified orange waste. J Mater Cycles Waste Manage 13(4):293-297

13. HELCOM (2013) Review of Fifth Baltic Sea Pollution Load Compilation for 2013 HELCOM Ministerial Meeting. Baltic Sea Environment Proceedings No. 141

14. Commission of European Communities (2014) Communication on the review of the list of critical raw materials for the EU and the implementation of the Raw Materials Initiative. (COM no. 297, 2014)

15. Scholz RW, Wellmer FW (2013) Approaching a dynamic view on the availability of mineral resources: What we may learn from the case of phosphorus? Glob Environ Change 23(1):11-27

16. Smol M, Kulczycka J (2017) Basic recommendations for the sustainable use of primary and secondary sources of phosphorus in Poland, "SYMPHOS 2017”. In: 4th International symposium on innovation and technology in the phosphate industry

17. Reijnders L (2014) Phosphorus resources, their depletion and conservation, a review. Resour Conserv Recycl 93:32-49

18. Commission of European Communities (2010) Communication. A strategy for smart, sustainable and inclusive growth Europe 2020 (COM no. 2020)

19. Commission of European Communities (2016) Communication on the Circular Economy Package. Proposal for a Regulation of the European Parliament and of the Council laying down rules on the making available on the market of CE marked fertilising products and amending Regulations (EC) No 1069/2009 and (EC) No 1107/2009 (COM no. 157, 2016)

20. Schoumans OF, Bouraoui F, Kabbe C, Oenema O, van Dijk KC (2015) Phosphorus management in Europe in a changing world. Ambio 44(2):180-192

21. Fischer P, Pöthig R, Venohr M (2017) The degree of phosphorus saturation of agricultural soils in Germany: Current and future risk of diffuse $\mathrm{P}$ loss and implications for soil $\mathrm{P}$ management in Europe. Sci Tot Environ 599:1130-1139

22. Le Noë J, Garnier J, Billen G (2018) Phosphorus management in cropping systems of the Paris Basin: from farm to regional scale. J Environ Manage 205:18-28

23. Zhou K, Barjenbruch M, Kabbe C, Inial G, Remy C (2017) Phosphorus recovery from municipal and fertilizer wastewater: China's potential and perspective. J Environ Sci 52:151-159

24. Seyhan D, Brunner PH (2018) The choice of system boundaries for effective long-term management of phosphorus. J Mater Cycles Waste Manage 20(1):345-352

25. Krüger O, Adam C (2015) Recovery potential of German sewage sludge ash. Waste Manag 45:400-406

26. Kowalski Z, Generowicz A, Makara A, Kulczycka J (2015) Evaluation of municipal waste landfilling using the technology quality assessment method. Environ Prot Eng 41(4):167-179

27. Generowicz A, Kulczycka J, Kowalski Z, Banach M (2011) Assessment of waste management technology using BATNEEC options, technology quality method and multi-criteria analysis. J Environ Manage 92(4):1314-1320

28. Generowicz A, Gaska K (2014) Research on waste generation indicators for 40 thousand inhabitants community. Arch Waste Manag Environ Prot 16(2):67-74

29. Li J, Yu K (2011) A study on legislative and policy tools for promoting the circular economic model for waste management in China. J Mater Cycles Waste Manage 13(2):103-112 
30. Krüger O, Adam C (2017) Phosphorus in recycling fertilizersanalytical challenges. Environ Res 155:353-358

31. Galos K, Nieć M, Saługa PW, Uberman R (2015) The basic problems of mineral resources valuation methodologies within the framework of System of Integrated Environmental and Economic Accounts. Gospodarka Surowcami Mineralnymi 31(4):5-20

32. Nieć M, Galos K, Szamałek K (2014) Main challenges of mineral resources policy of Poland. Resour Policy 42:93-103

33. Mineral Resources of Poland (2017). Polish Geological Institute National Research Institute. Eds. Szuflicki M, Malon A, Tymiński M, Poland, Warsaw 2017 (Mineral Resources of Poland 2017)

34. Minerals Yearbook of Poland (2014) Polish Geological Institute National Research Institute. Smakowski T, Galos K, Lewicka E (eds) Mineral and energy economy research institute of the Polish Academy of Sciences, Poland, Warsaw 2014 (Minerals Yearbook of Poland, 2014)

35. Environment 2017 (2017) Central Statistical Office, Warsaw 2017 (Environment, 2017)

36. Piwowar A (2013) Economic and financial situation of producers and the sypplu-demand changes in the mineral fertilizers market in Poland. Sci J Warsaw Univ Life Sci Prob World Agric 13(1):96106. (in Polish)

37. Science for Environment Policy Report 2017. https://ec.europa.eu/ Eurostat. Accessed 10 Mar 2018

38. Adam C (2009) Techniques for P-recovery from waste water, sewage sludge and sewage sludge ashes-an overview. In: Presentation at Baltic 21 conference phosphorus recycling and good agricultural practice, Berlin, 28-30 September 2009

39. Adam C, Gnirss R, Lesjean B, Buisson H, Kraume M (2002) Enhanced biological phosphorus removal in membrane bioreactors. Water Sci Technol 46(4-5):281-286

40. Egle L, Rechberger H, Krampe J, Zessner M (2016) Phosphorus recovery from municipal wastewater: an integrated comparative technological, environmental and economic assessment of $\mathrm{P}$ recovery technologies. Sci Total Environ 571:522-542

41. Krüger O, Grabner A, Adam C (2014) Complete survey of German sewage sludge ash. Environ Sci Technol 48(20):11811-11818

42. Gorazda K, Kowalski Z, Wzorek Z, Jodko M, Rzepecki T, Kulczycka J, Przewrocki P (2003) Possibilities of phosphorus recovering from municipal sewage and sewage sludge. Pol J Appl Chem 47(2):51-63

43. Li R, Yin J, Wang W, Li Y, Zhang Z (2014) Transformation of phosphorus during drying and roasting of sewage sludge. Waste Manag 34(7):1211-1216

44. Steckenmesser D, Vogel C, Adam C, Steffens D (2017) Effect of various types of thermochemical processing of sewage sludges on phosphorus speciation, solubility, and fertilization performance. Waste Manag 62:194-203

45. Kabbe C (2013) The limited resources of phosphorus and how to close the phosphorus cycle. In Factor X 30:261-273

46. Guedes P, Couto N, Ottosen LM, Ribeiro AB (2014) Phosphorus recovery from sewage sludge ash through an electrodialytic process. Waste Manag 34(5):886-892

47. Herzel H, Krüger O, Hermann L, Adam C (2016) Sewage sludge ash-a promising secondary phosphorus source for fertilizer production. Sci Total Environ 542:1136-1143

48. Jeng A, Haraldsen TK, Vagstad N, Grønlund A, Tveitnes S (2004) Meat and bone meal as nitrogen fertilizer to cereals in Norway. Agric Food Sci 13(3):268-275

49. Ylivainio K, Uusitalo R, Turtola E (2008) Meat bone meal and fox manure as P sources for ryegrass (Lolium multiflorum) grown on a limed soil. Nutr Cycl Agroecosyst 81(3):267-278
50. Staron P, Banach M, Kowalski Z (2013) Assessment of an application of ashes produced by incineration of poultry industry waste as a rich phosphorus source. Przem Chem 92(6):1142-1144

51. Kowalski Z, Makara A, Fijorek K (2013) Changes in the properties of pig manure slurry. Acta Biochim Pol 60(4):845-850

52. Klem-Marciniak E, Hoffmann K, Huculak-Wczka M, Hoffamann J, Makara A, Kowalski Z (2015) Fertilizer properties of filter sludge from pig slurry. Przem Chem 94(12):2158-2161

53. Johansson S, Ruscalleda M, Colprim J (2017) Phosphorus recovery through biologically induced precipitation by partial nitritation-anammox granular biomass. Chem Eng J 327:881-888

54. Tan Z, Lagerkvist A (2011) Phosphorus recovery from the biomass ash: a review. Renew Sustain Energy Rev 15(8):3588-3602

55. Kulczycka J, Kowalski Z, Smol M, Wirth H (2016) Evaluation of the recovery of Rare Earth Elements (REE) from phosphogypsum waste-case study of the WIZOW chemical plant (Poland). J Clean Prod 113:345-354

56. Gorazda K, Wzorek Z, Tarko B, Nowak AK, Kulczycka J, Henclik A (2013) Phosphorus cycle-possibilities for its rebuilding. Acta Biochim Pol 60(4):725-730

57. Wójcik M, Stachowicz F, Masłoń A (2017) The possibility of the application of fly ashes in order to the improvement of sewage sludge dewatering. J Civil Eng Environ Archit 64(1/17):377-393

58. Adam C, Peplinski B, Michaelis M, Kley G, Simon FG (2009) Thermochemical treatment of sewage sludge ashes for phosphorus recovery. Waste Manag 29(3):1122-1128

59. Szaja A (2013) Phosphorus recovery from sewage sludge via pyrolysis. Ann Set Environ Prot 15:361-370

60. Kulczycka J, Lelek L, Lewandowska A, Zarebska J (2015) Life cycle assessment of municipal solid waste management-comparison of results using different LCA models. Pol J Environ Stud 24(1):125-140

61. Amann A, Zoboli O, Krampe J, Rechberger H, Zessner M, Egle L (2018) Environmental impacts of phosphorus recovery from municipal wastewater. Resour Conserv Recycl 130:127-139

62. Smol M, Kulczycka J, Henclik A, Gorazda K, Wzorek Z (2015) The possible use of sewage sludge ash (SSA) in the construction industry as a way towards a circular economy. J Clean Prod 95:45-54

63. Wiśniowska E, Włodarczyk-Makuła M (2018) The effect of selected acidic or alkaline chemical agents amendment on leachability of selected heavy metals from sewage sludge. Sci Tot Environ 633:463-469

64. The plant in Jarocin will produce agricultural fertilizer from sediments. https://portalkomunalny.pl/oczyszczalnia-w-jaroc inie-wyprodukuje-nawoz-rolniczy-z-osadow-374791. Accessed 15 May 2018

65. Nelles M, Grünes J, Morscheck G (2016) Waste management in Germany-development to a sustainable circular economy? Procedia Environ Sci 35:6-14

66. A Circular Economy in the Netherlands by 2050 (2015) Ministry of infrastructure and the environment and the Ministry of Economic Affairs, also on behalf of the Ministry of Foreign Aff airs and the Ministry of the Interior and Kingdom Relations, government.nl/circular-economy, Netherlands 2015 (a circular economy in the Netherlands by 2050, 2015)

67. Seppälä J, Sahimaa O, Honkatukia J, Valve H, Antikainen R, Kautto P, Myllymaa T, Mäenpää I, Salmenperä H, Alhola K, Kauppila J, Salminen J (2016) Kier totalous Suomessa-toimintaympäristö, ohjauskeinot ja mallinnetut vaikutukset vuoteen 2030 (Circular economy in Finland-operational environment, policy instruments and modelled impacts by 2030, in Finnish with English abstract)

68. Norwegian Circular Economy Benchmark 2017, Deloitte AS and Circular Norway 2018 (NCEB, 2018) 
69. Roadmap Transformation towards a circular economy (2018) Ministry of Development. Warsaw 2018 (Roadmap Transformation towards a circular economy, 2018) (in Polish)

70. Towards a Circular Economy (2016), Ministry of the Environment. https://www.mos.gov.pl/en/news/details/controller/detai 1/News/news/towards-a-circular-economy-1 (towards a Circular Economy, 2016)

71. Smol M, Kulczycka J, Kowalski Z (2016) Sewage sludge ash (SSA) from large and small incineration plants as a potential source of phosphorus-Polish case study. J Environ Manage 184:617-628

72. Wisniowska E, Wlodarczyk-Makula M, Nowak R (2016) Effect of chemical stabilisation method on $\mathrm{Zn}$ and $\mathrm{Cu}$ forms in digested sewage sludge. Ann Set Environ Prot 18:783-793

73. Macherzyński B, Włodarczyk-Makuła M, Skowron-Grabowska B, Starostka-Patyk M (2016) Degradation of PCBs in sewage sludge during methane fermentation process concerning environmental management. Desalin Water Treat 57(3):1163-1175

74. Worwag M (2016) Impact of adding biopreparations on the anaerobic co-digestion of sewage sludge with grease trap waste. Civil Environ Eng Rep 22(3):167-179

75. Council Directive 99/31/EC of 26 April 1999 on the landfill of waste (LFD)

76. Act on waste of 14 December 2012 (Journal of Laws item 21, 2012)

77. Regulation of Minister of Economy on the acceptance of waste for landfill of 16 July 2015 (Journal of Laws item. 1277, 2015)

78. National Waste Management Plan 2014 (No. 101, item 1183, 2010) (in Polish)

79. Sadecka Z, Myszograj S, Sieciechowicz A, Płuciennik-Koropczuk E, Włodarczyk-Makuła M (2016) Impact of selected insecticides on the anaerobic stabilization of municipal sewage sludge. Desalin Water Treat 57(3):1213-1222

80. National Waste Management Plan 2022 (No. 88, item 784, 2016) (in Polish)
81. Commission of European Communities Country Report Poland 2017 (2017) Accompanying the document Communication from the Commission to the European Parliament, the Council, the European Central Bank and the Eurogroup. 2017 European Semester: Assessment of progress on structural reforms, prevention and correction of macroeconomic.c imbalances, and results of in-depth reviews under Regulation (EU) No 1176/2011 (SWD no. 86,2017 )

82. Opinion of the Senate Committee on the Environment on the innovative use of waste water as a source of energy and resources of 17 March 2016 (BPS/KS/0330/12/16) (in Polish)

83. Works of the Environment Committee. https://www.senat.gov.pl. Accessed 10th May 2018

84. Opinion of the Environment Committee of the Senate of the Republic of Poland on the protection of the Baltic Sea against pollution originating from sewage sludge in the context of the recommendation of the Helsinki Commission of 6 December 2017. https://www.senat.gov.pl

85. Schröder JJ, Cordell D, Smit AL, Rosemarin A (2010) Sustainable use of phosphorus. (European Union tender project ENV.B.1/ ETU/2009/0025). In: Report 357, Plant Research International. Wageningen University and Research Centre, Wageningen

86. Schweizer Bundesrat (2015) Verordnung Über die Vermeidung und die Entsorgung von Abfällen (VVEA); Ordinance on Avoidance and Disposal of Waste; Schweizer Bundesrat: Bern, Switzerland, 2015

87. BMU-Federal Ministry for the Environment, Nature Conservation, Building and Nuclear Safety (2017) Klärschlammverordnung-AbfKlärV (Sewage Sludge Ordinance). https://www. bmub.bund.de/themen/wasser-abfall-boden/abfallwirtschaft/wasse r-abfallwirtschaftdownload/artikel/klaerschlammverordnung-abfkl aerv/?tx_ttnews\%5BbackPid\%5D=608 